\title{
Bob Tollison: remarkable polymath and person
}

\author{
Fred S. McChesney ${ }^{1}$
}

Received: 26 December 2016/Accepted: 31 January 2017/Published online: 27 February 2017

(C) Springer Science+Business Media New York 2017

\section{Atque in perpetuum, frater \\ Ave atque vale ${ }^{1}$}

The passing of one truly great can only leave great sorrow. Hail and farewell, Robert Tollison. We shall not look upon your like again.

Two overlapping groups of economists mourn the death of Bob Tollison. The larger includes the many readers of his economics work, who never knew Bob personally, but benefited considerably from his many contributions to that literature. Bob's professional life left us with so many insights ("public goods," if you will), available to all and availed of by many.

Bob's economics oeuvre covers a vast territory, in an extraordinary number of subdisciplines, along both the extensive and intensive margins in all of them. Bob was a throw-back to Adam Smith (whom he never stopped recommending to colleagues and students) in his ability to range successfully across many economic terrains.

One suspects that Bob's astonishing breadth and depth in economics was partly a function of his graduate training at the University of Virginia. The early-1960s' publicchoice revolution simmering in Rouss Hall must have impressed Bob, with its alloy of traditional economics, politics and law that Buchanan and Tullock were molding. Or perhaps Bob already had sprung full-blown as a South Carolina polymath from the Spartanburg public schools and Wofford College. Regardless of the impetus, Tollison came to believe-and prove - that careful economics could explain important aspects of sports, religion, elections, and regulation. In the best sense, Tollison was an economics

\footnotetext{
1 Catullus, Carmen 101. "Now and forever, brother, Hail and farewell."
}

Fred S. McChesney

fsmcc@aol.com

$1 \quad$ University of Miami, Coral Gables, FL, USA 
know-it-all, very possibly the best combination of brains and versatility we ever have had, or will.

Certainly among the most genial, down-to-earth and just plain fun economists ever. This important aspect of Bob's personality made him a popular teacher. As one of his colleagues said, "Bob was the favorite professor of many students.... Although he had a huge intellect and was highly accomplished he never talked down to anyone." 2 On "Rate My Professor," one student wrote:

Tollison is unparalleled in his ability as a lecturer, as his experience reflects a quality that is quintessentially unique to great storytelling. He is, not only extremely intelligent and wholly knowledgeable about everything (yes, everything), but also, inspiring in the way he evokes interest in seemingly deathly dry topics in public choice.

Bob's extraordinary breadth concerning everything around him was evident to all. Indeed, to let Bob Tollison loose under your roof was almost a guarantee that theory, graphs and econometrics about your establishment would follow. ${ }^{3}$ In 1981, when picked by President Reagan to chair the Federal Trade Commission, Bob's UVA classmate James Miller tabbed Tollison to head the FTC's Bureau of Economics. Inevitably, Bob would use his position "in the belly of the beast," as he put it, to analyze the phenomenon he was part of regulating, namely antitrust.

Antitrust was an economic conundrum at the time. Economists felt that it was a benign exception to the increasingly accepted malign view that government regulation was itself anticompetitive. At the same time, however, empirical examination of the cases brought by the FTC and the Justice Department's Antitrust Division failed to reveal what exactly impelled government antitrust enforcement. Economists had tried for years to explain what explained antitrust cases brought by the government, but without success. Economic variables that should explain enforcement-profits, prices-did not. While economists could not explain what exactly of good was going on, there seemed no malignity afoot, either. To the extent that any rhyme or reason was plausible, enforcement seemed due to ignorant misperceptions and errors, albeit innocent ones.

But, of course, ignorance can explain anything and so explains nothing. The story of the campaign to save antitrust from economists' ignorance, inaugurated and led by Tollison, has been told in detail elsewhere (Shughart and McChesney 2010). It was vintage Tollison cutting the Gordian knot. He realized that the prior inquiries had used normative variables to try to model how the enforcers should have pursued cases. That in effect meant that enforcement was modeled in public-interest terms.

But, Bob noted, no realistic economist any longer accepted unskeptically a publicinterest version of a given government activity. Antitrust enforcement notably was a public-choice theorist's dream. The chief antitrust enforcers (the Attorney General, the Assistant Attorney General for Antitrust, the members of the Federal Trade Commission) are political appointees; their staffs are government employees with their own career goals. Both agencies interact with firms wanting to avoid the government's long arm and with

\footnotetext{
${ }^{2}$ Quoted in McCormick, "In Memoriam: Robert Dewitt Tollison," http.//newsstand.clemson.edu/inmemoriam-robert-dewitt-tollison/.

${ }^{3}$ Bob was a dedicated empiricist, although no practicing econometrician. He of course understood econometrics' importance in doing defensible and convincing empirical economics, but left the mechanics to his collaborators. He thus differed from his mentor Jim Buchanan, who dismissed empirics, famously remarking that he didn't need statistics to prove that water runs downhill.
} 
firms seeking redress for the injury flowing from alleged violations of the antitrust laws. Congress determines the budgets of the Antitrust Division and the FTC; congressional committees monitor their activities. Antitrust enforcers, like the legislators to whom they were beholden, are political animals, and none of the previous inquiries had included in their models the politics of enforcement.

Tollison's work on the economics of antitrust showed the way to viewing enforcement in public-choice rather than public-interest ways. Politics matters, as Bob demonstrated empirically with his seminal piece (Faith et al. 1982, published while he was at the FTC; see also Tollison 1983). Antitrust is a way to benefit one's constituents by bringing enforcement actions against their rivals, or by threats against one's own constituents who do not respond acceptably to politicians' demands. The literature has become vast, and solely public-interest discussion of antitrust is no longer intellectually tolerable (at least outside Washington). Now, thanks to the intellectual élan developed launched Bob at the FTC, analysis of antitrust that includes politics has become commonplace (e.g., Coate et al. 1990).

Having Bob around the FTC meant intellectual ferment throughout the building. Papers (and ultimately articles) began to appear, based not on the FTC economists' in-house analyses of particular cases, but big-think pieces from within and without the agency about why we observe what we do in the world of antitrust regulation. Memorably, Gordon Tullock presented a paper at the Bureau of Economics during these halcyon days, a sure sign that the times were a-changing. Sitting around with Bob and other like-minded truth seekers, from within or outside the walls, was almost a second graduate economics education.

The antitrust re-evaluation fermented elsewhere. Consumer protection was another particularly fertile source of inquiry. It comprises half of the FTC's regulatory jurisdiction, but its economics were so little understood at the time (and in several respects have advanced little since). Why did we need a national statute outlawing "unfair and deceptive acts and practices in commerce" (the Federal Trade Commission Act of 1914, as amended), when fraud had been illegal at common law for centuries? Why federal rules on reporting things like credit terms or contract-sale disclosures (and policemen like the Federal Trade Commission to enforce the federal requirements), when state law already has or could legislate its own regulations? Our sessions on such topics, often no more rigorous than a lunch-time bull session, were captivating, stimulated by Bob's insistence and constant encouragement that preliminary ruminations will often lead to harder, more defensible explanations. ${ }^{4}$

Although any number of other areas of Tollisonian work could have been noted (Tollison and Wagner 1991), Bob's obituaries most frequently pointed to two areas outside public choice and regulation where he made his greatest publishing splashes, starting with sports economics. Because the economics of sports, especially the rule-making activities of the National Collegiate Athletics Administration (NCAA), involve areas in which I was involved only as a reader, I shall leave others to comment on those parts of Bob's resume. They have been cited and referred to often since their publication. Can there be any doubt that the justifications offered by the NCAA for their college-sports cartel increasingly are seen as self-serving ways to earn prodigious rents, largely unshared with its labor inputs on the field? Bobby McCormick notes likewise that, "It is almost certain that the NBA

\footnotetext{
4 Shortly after leaving the FTC, Bob's influence was reflected in a sometimes cited paper and subsequent book of mine in that purely Tollisonian vein (McChesney 1987, 1997).
} 
[National Basketball Association] would not have added a third referee when it did without the research, advice and opinion of Bob Tollison." 5

Tollison's thinking about the sports cartel was in a sense a throw-back to his graduate years at Virginia, where he wrote his dissertation (under Jim Buchanan, with Roland McKean serving as his second reader) on a major issue of those Vietnam years, the allvoluntary army. His work was part of the influential book published in 1968-by a cadre of UVA graduate students-against the draft (Tollison 1968a, b). That graduate students then were writing topically for general publication, without today's economic/mathematic pyrotechnics, is astonishing. The book is just about monopoly rents and Tullockian rentseeking.

Given his public-choice interests in other areas like the army and the NCAA, it was inevitable that religion would cross his Bob's sights. As others wrote,

Most people consider the economics of religion to be a new field of research, but Bob Tollison knows better. Even if Adam Smith had not set the stage for investigations to the economics of religion...Tollison's interests, training and disposition would have pulled him into this research vortex. Indeed, it would be difficult to find a field more amenable to the analytic tools of public choice and industrial organization, fields on which Tollison cut his academic teeth. (Ekelund and Hébert 2010, p. 429)

Bob's application of economics to religion was a bit more fitful than in other areas. Analyzing a practice, by a particular institution in a given time and place, lends itself relatively well to economic modeling (Ekelund et al. 1989). And so familiar analysis of monopolization and rent seeking in the early Catholic church was well received (Ekelund and Tollison (2011). But extension of the model to other times and practices, when the institutions' underlying cost-benefit rules driving those in authority change appreciably and constantly, is not easy. In the economic analysis of religion, Bob came, saw and conquered. But then departed, given the time-demands of remaining to educate others in this evolving field.

Others in this volume will add much about Bob Tollison's substantive contributions to economics. Let me, though, turn to Bob as a person, and by way of example to his contribution to one particular economist—me. I met Bob in the late 1970s at the University of Miami, while he was in residence at Henry Manne's Law and Economics Center and where I was a fellow, still working on my dissertation. In short, Bob already was a somebody and I was not even close.

No matter. Maybe it was that South Carolinan birth and breeding, but one's niche in life meant nothing to Bob. We did have much in common that did matter to him. I regularly reviewed books for the Miami Herald, and Bob read incessantly. (As I recall, he was particularly fond of Southern fiction, but his reading, like his economics, worked along many margins.)

We also had much to share concerning sports, before Bob added that domain to his professional repertoire. We spent many sweaty afternoons and evenings in pick-up basketball games in the parking-lots of the University of Miami. I was taller and younger, and so did not think that pairing with Bob would prove a complement on the asphalt; with him on the team, we would spend more time waiting to get on the court than actually playing.

But I quickly learned that Bob was something I was not: a shooter. Indeed, with his modest stature and equally modest demeanor on the court, Bob was a stealth weapon until

5 McCormick, In Memoriam: Robert Dewitt Tollison, newsstand.clemson.edu/in-memoriam-robert-dewitttollison. 
the opposition cottoned on to him-when it often was too late. We won games because opponents would give him outside shots, which he then drained and we stayed on the court. I was not surprised to learn later that he was a basketball star at Spartanburg High. ${ }^{6}$

I could go on about sports, about how Bob (along with Anna and April) and I attended many University of Miami baseball games. Great chances for economics exchange and non-economic repartee (although Bob would not admit that the latter category was much more than a null set). But it would all be to make the same point. Maybe he was up there and I was down here, but we were all in the same business. And that's what mattered. As one who did not care whether or not he was judged, or how, Tollison himself simply did not judge others. He was the consummate economics party-giver: come as you are, be yourself, let's sit down and chat. ${ }^{7}$

I did come to understand that I had one virtue in Bob's eyes. Though still short of my doctorate, I was about to become a University of Virginia Ph.D. This in itself might seem of scant importance, but I learned that at that margin it mattered. Once I joined the doctoral inner sanctum, Bob went out of way to include me in the unofficial club of Virginia graduates that comprised his classmates and fellow graduates: Matt Lindsay, Richard Higgins, Dick Wagner, Tom Willett, Craig Stubblebine, Jim Miller, and others. (Others in the Virginia pantheon like Charlie Goetz, Mark Pauly and Charlie Plott I would meet only later.) It was thanks to Bob that I met and ultimately spent considerable time with Jim Buchanan and Gordon Tullock, an unforgettable privilege in any economist's life.

All were welcome. Bob was too much a gentleman, simply too kind a man, to treat anyone as an outsider. But a select few of us were special, and we knew it, because Bob showed it in his own quiet ways. Plus, which, he realized that with a spoonful of sugar, today's skeptics might well be tomorrow's believers.

In 1984, Bob asked me to become General Counsel of the Southern Economic Association (SEA), of which he was then president. Teaching both economics and law at Emory University at the time, I was honored by his request, though at first I did not know why the SEA needed a lawyer, which it had never had. ${ }^{8}$ I learned that Bob believed that the Association's relationship with the University of North Carolina (UNC) was harming the SEA in financial and other ways. The SEA-UNC link was longstanding, and the Association had been informed more than once that, as a legal matter, severing it would be difficult and costly. There was no real proof thereof-absent true documentation, there were only vague claims - and Bob wanted the matter investigated legally.

That was my job, and it resulted in evidence that the UNC-SEA tie was the result of historical happenstance only, with no legal bind on the SEA from sundering it. Which we did, without resistance from UNC, to the enormous institutional strengthening (including financial) that Bob had foreseen. The SEA presided over by Bob in 1984 was a precarious organization, both in finances and membership; today, it thrives in both respects.

The public good Bob created for economics has been large, not just in his writing but his institutional services, such as with the SEA. And his teaching and other work with students. McCormick says he signed more than 150 doctorates and master's theses. Do the math on how many per year that is, and then look at your own records. As one who has been there can attest, approaching Bob with a request was as good as having it granted.

\footnotetext{
${ }^{6}$ But I learned that from Bobby McCormick, not from Bob Tollison.

7 Here, Bob differed from his mentor, Jim Buchanan. As Bob himself noted, "For sure Jim did not suffer fools gladly" (Tollison 2013). Bob did (or at least might).

8 The honor was strictly whatever accolade attached to the position, which was and remains strictly pro bono.
} 
When a colleague saw Bob Tollison coming down the hall, it brought a smile of anticipation. Fun conversation and engaging economic discussion awaited. But as one came to know Bob, one realized that as he approached you, he was smiling, too-as happy to see you as you were to see him. My seeing his photo now just recalls his exceptional joie de vivre. With a great sense of loss.

One of Bob's student-raters put it this way: "This guy is a badass.... He isn't the easiest but he is so smart and is willing to help so much, TAKE HIM."

Badass Bob. The Tollison we knew, so smart and so willing to help. So great to be with, always and in all settings. To repeat, we will not see his like again.

\section{References}

Coate, M., Higgins, R. S., \& McChesney, F. S. (1990). Bureaucracy and politics in FTC merger challenges. Journal of Law and Economics, 33, 463-482.

Ekelund, R. B., Jr., Hébert, R. F., \& Tollison, R. D. (1989). An economic model of the medieval church: Usury as a form of rent seeking. Journal of Law Economics and Organization, 5(2), 307-331.

Ekelund, R. B., Jr., \& Hébert, R. F. (2010). Interest groups, public choice and the economics of religion. Public Choice, 142, 429-436.

Ekelund, R. B., Jr., \& Tollison, R. D. (2011). Economic origins of Roman Christianity. Chicago: University of Chicago Press.

Faith, R., Leavens, D., \& Tollison, R. D. (1982). Antitrust pork barrel. Journal of Law and Economics, 25, 329-342.

McChesney, F. S. (1987). Rent extraction and rent creation in the economic theory of regulation. Journal of Legal Studies, 16, 101-118.

McChesney, F. S. (1997). Money for nothing: Politicians, rent extraction and political extortion. Cambridge: Harvard University Press.

Shughart, W. F., II, \& McChesney, F. S. (2010). Public choice theory and antitrust policy. Public Choice, 142(3-4), 385-406.

Tollison, R. D. (1968a). Racial balance and the volunteer army. In J. C. Miller III (Ed.), Why the draft? The case for a volunteer army (pp. 149-158). Baltimore: Penguin.

Tollison, R. D. (1968b). An army of mercenaries? In J. C. Miller III (Ed.), Why the draft? The case for a volunteer army (pp. 159-165). Baltimore: Penguin.

Tollison, R. D. (1983). Antitrust in the Reagan administration: A report from the belly of the beast. International Journal of Industrial Organization, 1, 211-221.

Tollison, R. D. (2013). James M. Buchanan: In memoriam. Southern Economic Journal, 80, 1-4.

Tollison, R. D., \& Wagner, R. E. (1991). The economics of smoking: Getting it right. Dordrecht: Kluwer Academic Publishers. 